\title{
US seeks a big increase in wind power
}

[BOsTON] The Clinton administration has announced a major initiative to stimulate the use of wind as an energy source. In particular, it has set a goal of increasing the proportion of electricity produced by wind turbines from 0.1 per cent of the national total to 5 per cent by 2010 .

Addressing the annual meeting of the wind-energy industry in Burlington, Vermont, last month, energy secretary Bill Richardson unveiled the Wind Powering America programme, which calls for dramatically increased reliance on wind energy.

The programme is to be funded through budget requests for the Department of Energy (DoE) and other federal agencies, as well as private-sector investments.

"Wind energy has been the fastest growing source of energy in the world during the past decade and now represents a major economic opportunity for the United States," said Richardson. He pointed out that the power harnessed from wind world-wide exceeds 10,000 megawatts.

He added that the programme "will help combat global climate change by reducing carbon emissions". The greater use of wind energy, he said, could lead "the charge in the transition to renewable energy".

The federal government has promised to increase its own use of wind power to 5 per cent by 2010 by installing wind turbines purchasing wind-generated electricity.

Richardson said that research and development into wind power should be expanded to halve the cost of electricity from wind generators. He also announced \$1.2 million in energy department grants to ten states to support wind-energy projects.

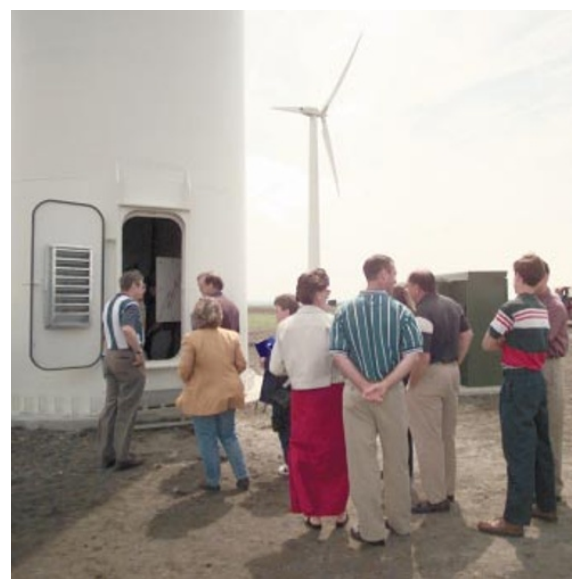

Blown along: Kansas residents inspect the state's first two wind generators, dedicated last month.

The proposals were enthusiastically greeted in Burlington. "This is the most visible and aggressive commitment to wind energy I've seen in my 20-plus years in the industry," says Randall Swisher, executive director of the American Wind Energy Association, which sponsored the four-day conference, Windpower ' 99.

Tom Gray, the group's deputy director, says the programme "recognizes that wind is the biggest success story in the renewableenergy field, and the closest to being commercially competitive".

Wind turbines produce electricity at about 5 cents per kilowatt hour, roughly an eightfold drop since 1980, according to Richardson. Costs have declined as turbines have become larger, more efficient and more reliable. "Early generations of turbines had a variety of problems that we've gradually been able to eliminate," says Dan Reicher, assistant secretary for energy efficiency and renewable energy at the DoE.

But wind still needs some help to narrow the gap with the cheapest fossil-fuel sources, says Reicher. The DoE is working with manufacturers to cost cuts by designing lighter turbines with improved aerodynamics and enhanced power-conversion systems.

The department also endorses a package of financial incentives to promote wind use. A production tax credit expired on 30 June, but the Clinton administration hopes to extend this and has backed a bill requiring electricity suppliers to use renewable sources for 7.5 per cent of the power generated by 2010 .

The DoE plans to sponsor several studies, including an assessment of power transmission capacity, an analysis of wind resources throughout the country, and siting reviews to ensure that birds would not be harmed by turbines. Training programmes will be set up for wind-turbine engineers and technicians.

The initiative also calls for a tripling in the number of states with significant windpower capacity (exceeding 20 megawatts) by 2010. DoE officials do not expect major objections to the technology on noise or aesthetic grounds, as most installations should go up in remote agricultural land.

Wind turbines could provide major economic benefits to farmers, says Reicher, and could serve as a new 'cash crop'. In time, the United States can go well beyond capturing 5 per cent of its electricity from wind, he adds.

But the administration must first secure the funding to advance wind technology. Wind might then become the major power source its proponents envisage. SteveNadis

\section{Mexican project shows that emissions reductions could be traded}

[WASHINGTON] A pilot project involving Mexico and Norway has shown that reductions in greenhouse gas emissions from developing countries can be satisfactorily measured and certified for 'trading' purposes.

Under the \$23 million Ilumex project, residents in two Mexican cities, Guadalajara and Monterrey, replaced millions of ordinary light bulbs with energy-efficient fluorescent bulbs that use a quarter of the power and last ten times as long.

Auditors say the move generated energy savings that reduced carbon dioxide emissions from Mexican power stations by more than 170,000 tonnes from 1995 to 1998. The reduction was certified by Det Norske Veritas, an independent foundation based in Oslo, with assistance from the US engineering consultancy ICF.

Sceptics argue that such reductions are difficult to measure and that international trading in emissions credits will be prone to fraud. But Kristian Holthe of Norway's ministry of foreign affairs, announcing the certification at the World Bank in Washington last week, said the pilot shows that it is possible to measure and certify emissions reductions attributable to particular projects. He said it "bodes well for the implementation of the Kyoto Protocol" to reduce emissions.

The parties to the protocol have yet to reach agreement on mechanisms for trading emissions credits. For example, developed nations may be able to obtain credits towards meeting emissions targets by helping developing nations to reduce their emissions.

The Global Environment Facility - an offshoot of the United Nations and the World Bank — paid \$10 million towards Ilumex, a sum matched by the Mexican electricity company Comision Federal de Electricidad, while the Norwegian government contributed $\$ 3$ million.

Most of the money was used to subsidize the sale of the more expensive fluorescent light bulbs. Auditors checked the sale and installation of the bulbs, their performance and their effect on carbon dioxide emissions.

Bob Watson, environment director at the World Bank, added that arrangements for trade or exchange of emissions credits were unlikely to be agreed until the sixth meeting of the conference of the parties to the United Nations Framework Convention on Climate Change, expected to be held late in 2000.

Supporters of emission controls hope that such a framework will open the way for global compliance with the Kyoto Protocol. But the US Senate remains hostile to the protocol, and is not expected to ratify it in the near future.

Colin Macilwain 